\title{
ANALYSIS OF FACTORS AFFECTING POVERTY IN NORTH SUMATERA PROVINCE (CASE STUDY IN 33 DISTRICT / CITY)
}

\author{
Yudistira Avandi ${ }^{1 *}$, Setyo Triwahyudi ${ }^{2}$ \\ 1*) Postgraduate Program, Universitas Negeri Medan \\ ${ }^{2}$ Faculty of Economics and Business, Universitas Brawijaya \\ Email: yudistiravandi@gmail.com
}

\begin{abstract}
The equitable poverty reduction in North Sumatera became one of the unresolved issues until now. The decreasing of poverty percentage in the last five years in North Sumatera can not represent the level of public welfare. In fact, in 2013, there were 22 out of 33 districts in North Sumatera which have the poverty percentage more than ten percent and known as hardcore poverty. The highest poverty percentage was found in North Nias and Gunung Sitoli by $30.94 \%$, while the lowest was found in Deli Serdang by $4.71 \%$. This research stated the problem "How is the influence of the economic growth, level of education, and the minimum regional wages toward the level of poverty in North Sumatera Province? The objective is to analyze the influence of economic growth, the level of education and the minimum wages toward the poor population in North Sumatera Province. This research used 165 samples that spread in 33 districts in North Sumatera from 2009 until 2013 with panel data and using Fixed Effect Model Method. The result of the Ordinary Least Square Method (LOS) through the multiple linear regretion estimated model showed that the economic growth and the minimum regional wages had negative influence, while the level of education had positive influence toward poverty in North Sumatera. The coefficient of determination $\left(R^{2}\right)$ is 0.948157 which means the variable of economic growth, minimum regional wages and level of education can define the poverty in North Sumatera by $94.82 \%$, and $5.18 \%$ defined by other economic variables outside the model.
\end{abstract}

Key words: Poverty, Economic Growth, Minimum Regional Wages, North Sumatera, Fixed Effect Model, Multiple Linier Regretion

\section{INTRODUCTION}

n orth Sumatera as a province with the fourth largest population in Indonesia with 33 city regencies contained in it is certainly one of the great potentials in Indonesia. The provincial government of North Sumatera as a government unit is of course very serious and continues to make efforts in overcoming the problem of poverty. This can be seen from the reduction in the percentage of poverty from year to year. In 2009, the poverty rate for North Sumatera was 11.51 percent, while in 2013 it was at 10.39 percent. 
Table 1: Poverty Percentage in North Sumatera, 2009-2013

\begin{tabular}{lc}
\hline Year & Poverty Percentage \\
\hline 2009 & 11.51 \\
2010 & 11.31 \\
2011 & 11.33 \\
2012 & 10.41 \\
2013 & 10.39
\end{tabular}

Source: BPS North Sumatera Province 2013

Equitable poverty reduction in North Sumatera is one of the unresolved problems to date. It turns out that the reduction in the percentage of poverty in the last 5 years in North Sumatera has not been able to represent the level of welfare of the people of North Sumatera. The actual conditions in the field of 33 urban districts in North Sumatera are 22 districts / cities whose poverty percentage in 2013 was more than 10 percent or known as hardcore poverty. Where the regions with the highest percentage of poverty were North Nias Regency and Gunung Sitoli City, which amounted to 30.94 percent, while the lowest poverty percentage in North Sumatera was in Deli Serdang district, which was 4.71 percent.

This is of course a task that must be completed immediately by the provincial government of North Sumatera. Equitable development to all districts / cities in North Sumatera, of course, must be done immediately. The development process certainly requires high regional income and fast economic growth. In many countries the main condition for a steady reduction in poverty is economic growth. Economic growth is indeed not enough to alleviate poverty but usually economic growth is something that is needed, even so, even good economic growth will not mean a decrease in the poor if it is not accompanied by equal income distribution (Wongdesmiwati, 2009).

Economic growth alone is likely to benefit only a small part of society and leave a large proportion of the poor behind. Meanwhile, prioritizing equity alone without high economic growth will not be able to improve welfare or only revolve around poverty distribution. Therefore, a country's economic policies must be formulated to be more pro-growth (spurring economic growth), pro-jobs (expanding employment), and propoor (reducing poverty) (Maipita et al, 2010).

The amount of minimum wage for workers which is determined by government policy also affects the level of poverty. The minimum wage policy in Indonesia itself was first implemented in the early 1970s. However, the implementation was not effective in these years (Suryahadi et al, 2003). The Indonesian government only started paying more attention to the implementation of minimum wage policies in the late $1980 \mathrm{~s}$. This is mainly due to pressure from the international community regarding issues concerning violations of labor standards that have occurred in Indonesia.

According to Law No. 13 of 2003, it is stated that the minimum wage is only intended for workers with a working period of 0 (zero) to 1 (one) year. From this definition, there are two important elements of the minimum wage (Sumarsono, 2003), namely: 
1. Starting wage is the lowest wage a worker must receive when he is first hired to work.

2. The minimum wage amount must be able to meet the minimum living needs of workers, namely the need for clothing, food and household needs.

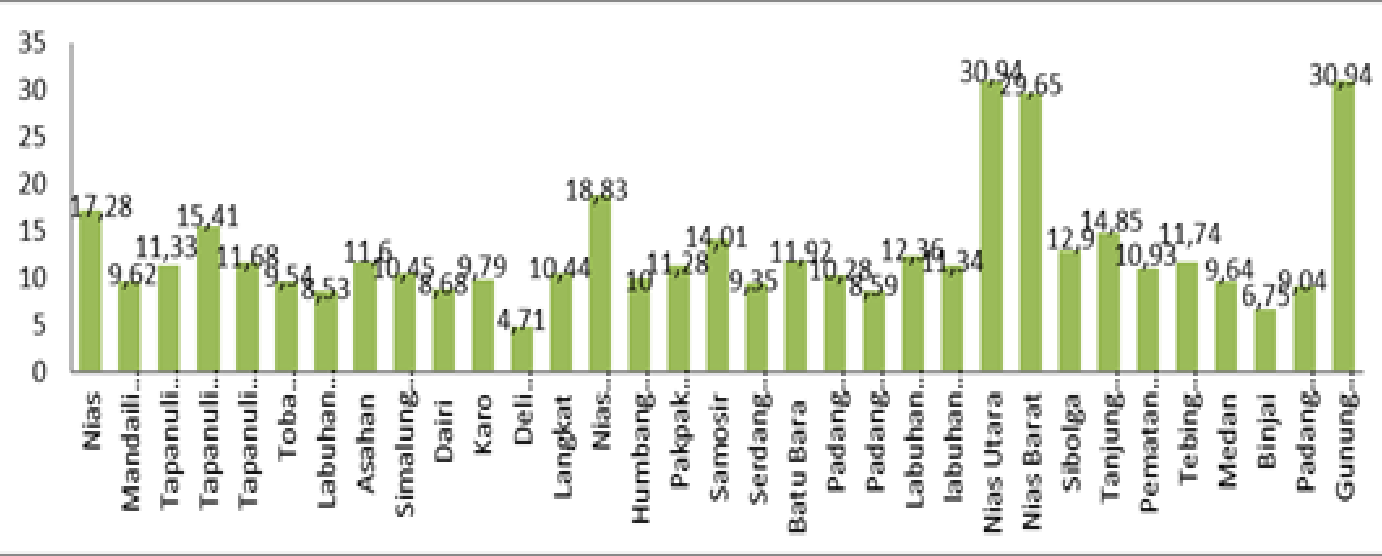

Figure 1: Percentage of Poverty in Districts / Cities in North Sumatera in 2013 Source: BPS North Sumatera Province 2013

Sumarsono (2003) also argues that wages are the main source of income for a worker, so that wages must be sufficient to meet the needs of workers and their families fairly. The limit of fairness in the Minimum Wage Policy in Indonesia can be assessed and measured by the Minimum Living Needs (KHM) or it is often called the Decent Living Needs (KHL).

(UMP) in North Sumatera Province continues to increase from year to year. In 2009 the minimum wage rate was 905,000 rupiah, then increased to 965,000 rupiah in 2010 and $1,035,500$ rupiah in 2011 . The highest increase occurred in 2013 , from $1,200,000$ rupiah in 2012 to $1,305,000$ rupiah.

Table 2: Development of Provincial Minimum Wages (PMW) in North Sumatera Province, 2009 - 2013 (in Rupiah)

\begin{tabular}{cccc}
\hline Year & PMW & \% increase & Inflation (\%) \\
\hline 2009 & 905.000 & 10.07 & 2.61 \\
2010 & 965.000 & 6.63 & 8.00 \\
2011 & 1.035 .500 & 7.31 & 3.67 \\
2012 & 1.200 .000 & 15.89 & 3.86 \\
2013 & 1.305 .000 & 8.75 & 10.18 \\
\hline
\end{tabular}

Source: BPS North Sumatera in Figures of Various Years of Publication, (processed)

Based on the observations in table 1 above, we can see that in 2010 and 2013 the percentage of the inflation rate that occurred in North Sumatera was higher than the percentage of the provincial minimum wage increase. The rate of increase in inflation which is higher than the rate of increase in the PMW will certainly reduce the welfare of workers.

Another factor that affects poverty levels is education. The correlation between education and poverty has long been a central issue in many countries, both developed 
and developing countries. Even in developed countries such as the United States, problems arise as a result of the large subsidies allocated to the poor (Carey, 2002). Meanwhile in Indonesia the problem lies in the injustice in gaining access to education between the rich and the poor. Where the costs for schools for the rich and the poor are relatively the same regardless of their family's economic background (Nurdyana et al, 2012).

The new growth theory emphasizes the importance of the role of government, especially in enhancing human capital development and encouraging research and development to increase human productivity. The fact can be seen that investing in education will be able to improve the quality of human resources as shown by increasing one's knowledge and skills. The higher a person's education level, the knowledge and expertise will also increase so that it will encourage an increase in work productivity. The low productivity of the poor can be caused by their low access to education (Sitepu and Sinaga, 2004).

Based on the above background, North Sumatera Province in 2009 - 2013 experienced a decrease in the poverty rate each year, but the reduction in the poverty rate was not evenly distributed in 33 districts / cities in North Sumatera province. Therefore, further research is needed to find out what factors affect poverty in North Sumatera Province so that later it can be used as a basis for making economic policies.

One of the indicators of a country's economic success can be calculated by measuring economic growth. Economic growth is marked by an increase in GDP (Gross Domestic Product) which in turn has an impact on the movement of production that requires resources, be it natural resources, human resources and capital resources.

The higher the education level of human resources or workers, of course, will have an impact on production results in accordance with the company's targets. However, considering the high unemployment rate which is directly proportional to the poverty level, it has caused a growing polemic in society. This condition is faced with the increasing number of schools and universities that are developing in the country which annually produce educated workers. However, not all of these workers are able to fill the available jobs.

The amount of wages given by employers to workers is a form of appreciation for the work done by workers. Worker satisfaction with the amount of wages received depends on the welfare of the workers themselves. When wages do not guarantee the welfare of life and even fulfill the basic needs of workers, it can be ascertained that the amount of wages is in favor of the interests of producers or employers who want to maximize their profits without paying attention to the welfare of workers.

The three economic variables mentioned above, according to the author, need to be investigated further whether these variables affect the poverty level. So that according to the author, a frame of mind can be drawn as below.

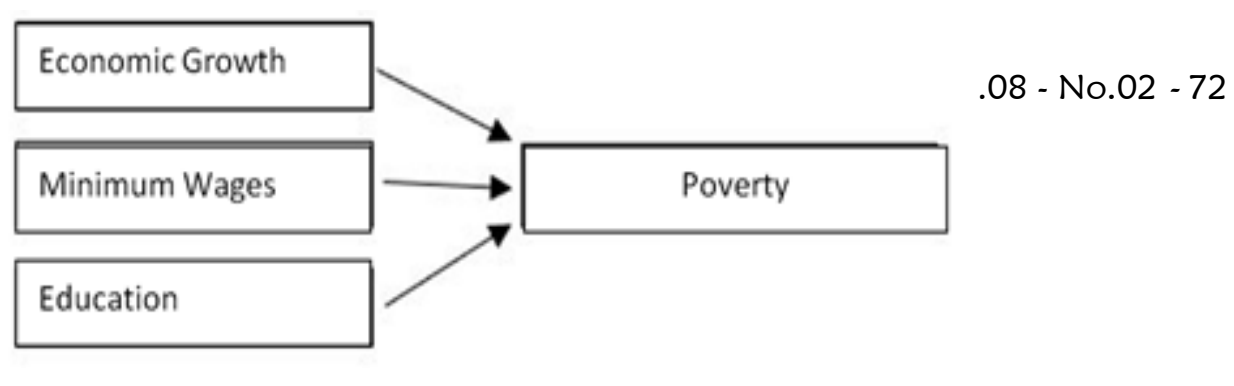


Figure 2: Research Conceptual Framework

\section{RESEARCH METHOD}

This study uses panel data analysis (pooled data). Where the goal is to determine the effect of the level of economic growth, minimum wages, and education on poverty levels in the province of North Sumatera. The variables in this study are:

1. Poverty rate $(K)$, namely the population who were below the poverty line in 33 districts / cities in North Sumatera Province in 2009-2013 (in percent).

2. Regional Economic Growth (Y), expressed as changes in GRDP at constant prices in 33 Regencies / Cities of North Sumatera Province (in percent) in 2009-2013.

3. District / City Minimum Wage $(U)$ is the minimum wage applicable in each region that is received by workers monthly. Minimum Wagesused in this study is the minimum wage that applies in 33 regencies / cities of North Sumatera Province in 2009-2013 which is measured in rupiah units.

Education is defined as the population aged 10 years and over who passed the last high school education and above in 33 Regencies / Cities of North Sumatera Province in 20092013 which is measured in percentage units. In the preparation of this study the data used are secondary data taken from the Central Statistics Agency of North Sumatera Province and the Office of Manpower and Transmigration of North Sumatera Province. Secondary data used is time series data for the period 2009-2013. As well as cross section data covering 33 districts / cities in North Sumatera Province.

The data collection technique in this research is through documentary studies, namely by collecting data through written documents, journals, certain books, opinions, theories and using secondary data sourced from the North Sumatera Central Statistics Agency (BPS) and Department of Manpower and Transmigration of North Sumatera Province for the period 2009 - 2013. By analyzing the data obtained, to find out how much influence the independent variables have on the dependent variable using an econometric model by regressing the existing variables using the Panel Data Regression Model. The data used were analyzed quantitatively by using statistical analysis, namely multiple linear regression equations. The independent variable that affects the dependent variable is stated in the following functions:

$$
Y=f(X 1, X 2, X 3)
$$

Then the function is transformed into a multiple linear equation model (multiple regression).

\section{RESULT AND DISCUSSION}

QE Journal | Vol.08 - No.02 - 73 
The interpretation of the final model selection used in this study is in accordance with the results of the data output and in accordance with the tests that have been carried out in this study, namely the model used is the Fixed Effect Model. As is known in the Fixed Effect Model, differences in individual characteristics and time are accommodated in the intercept so that the Poverty Level intercept of each Regency / City in North Sumatera Province is different as well as the different constants so that the model equation is different for each Regency. / Cities in North Sumatera Province are also different. But in general the similarities of this research are as follows:

\section{$\mathrm{K}=6.655604-0.096160 \mathrm{PE}-0.527968 \mathrm{MW}+1.042747 \mathrm{ED}$}

1. The poverty rate regression coefficient based on the above data processing results is 6.655604, which means that the normal poverty rate in North Sumatera is 6.66 percent of the population. This condition applies when the economic variables that affect poverty in this study are considered to be constant (fixed) or unchanged. The highest normal poverty conditions in districts / cities in North Sumatera Province were South Nias District at 1.518315 and North Nias at 1.473788. This means that in the condition other variables that influence in this study are constant or unchanged, the normal poverty rate in the two districts is 1.518315 percent and 1.473788 percent of the population in the regency. Meanwhile, the lowest level of poverty was found in Deli Serdang Regency which was -1.242673 and Binjai City which was -1.091363 . Medan City which is the capital city of North Sumatera province has a normal poverty rate of -0.892924 , meaning that based on the results of this study, the normal poverty rate in Medan City is -0.892924 percent.

2. The economic growth regression coefficient is -0.096160 , which means that an increase in economic growth of 1 percent will reduce the poverty rate by 0.09 percent. The results of this study are in accordance with the hypothesis and previous research conducted by Permana and Fitrianti (2012) and Dollar and Kraay (2001) in Maipita (2014) which indicate a negative relationship between economic growth and poverty levels where an increase in economic growth will lead to a decline. poverty level. This study is also in accordance with Kuznet's theory which states that poverty has a very strong correlation, because the early stages of the development process the poverty rate tends to increase, but as it approaches the final stage of development the number of poor people will gradually decrease.

3. The district / city minimum wage coefficient is -0.0527968 . This means that an increase in the minimum wage of 1 percent will reduce the poverty rate by 0.0527968 percent. This result is in accordance with the hypothesis and previous research by Riva et al. (2014) who found a negative relationship between wages and poverty levels in Riau Province where the increase in wages has an impact on reducing the level of poverty.

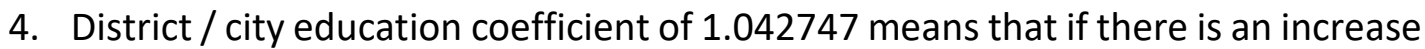
in education by 1 percent, the poverty rate in the province of North Sumatera will increase by 1.042747 percent. This result is not in accordance with the 
hypothesis and previous research by Permana and Fitrianti (2012) which resulted that education had a negative and significant effect on the percentage of poor people in Central Java. This study is in accordance with the results of Dewi and Endrayani's (2016) research which resulted that the level of education directly showed a positive and significant influence on the poverty level in Bali Province. The higher education that the community has makes them demand high wages according to what they want, if the company is deemed not to provide appropriate wages, they will choose to wait for jobs according to their wishes (Hajji and Nugroho in Dewi, 2016). An increase in the number of educated workers without being accompanied by an increase in the absorption of labor can create new problems in national development. There is a mismatch between the quality of graduates and the needs of the business world or educational institutions that are unable to produce ready-to-use graduates according to the needs and demands of national economic development (Tobing in Juwita 2011). Data from the Ministry of Manpower and Transmigration shows that around 30 percent of job vacancies in 2010 were not filled. In fact, the number of job seekers is abundant. The character and competitiveness of job seekers is a problem. Data from provinces, districts and cities shows that there are 4.12 million job seekers registered, while job vacancies are available for 2.38 million people, of which only 1.62 million people are filled (about 70 percent). The reality that has occurred in the last 15 years is that the unemployment rate of higher education graduates has increased. This situation shows that equal opportunity to obtain quality education is a major problem in the education sector, while quality education will certainly form reliable human resources (Hariani, 2011).

\section{CONCLUSIONS AND RECOMMENDATIONS}

\section{Conclusion}

Based on the results of the analysis and discussion that has been stated, several conclusions can be drawn as follows:

1. The effect of Economic Growth (EG) on the Poverty Level (P) in 33 Regencies / Cities of North Sumatera Province can be said to have a negative and insignificant effect. This can be seen from the results of the regression test which has a sig value of $0.5739<0.05$, because a sig value of not less than 0.05 means that there is a negative and insignificant effect.

2. The influence of the education level of the population aged 10 years and over who passed the last high school education and above (E) on the Poverty Level (P) in 33 Regencies / Cities of North Sumatera Province can be said to have a positive and significant effect. This can be seen from the results of the regression test which has a sig value of $0.0000<0.05$, because a sig value of less than 0.05 means that there is a positive and significant effect.

3. The influence of the Regency / City Minimum Wage in 33 Regencies / Cities of North Sumatera Province can be said to have a negative and significant effect. This can be seen from the results of the regression test which has a sig value of

QE Journal | Vol.08 - No.02 - 75 
$0.0000<0.05$, because a sig value of less than 0.05 means that there is a negative and significant effect. Thus the hypothesis is proven.

\section{Suggestion}

Based on the results and conclusions of the study, the suggestions that can be put forward by the author are as follows:

1. It is recommended that the government pay attention to and maintain economic growth through the stability of the level of production of goods and services in North Sumatera in 33 districts / cities in North Sumatera Province. If economic growth is well maintained and is in a stable condition, this will have an impact on the amount of production that is stable and may even increase so that jobs will be wide open which can be filled by people who do not have a job.

2. It is recommended that the government needs to adjust the Regency / City Minimum Wage by taking into account the need for decent living and the welfare of the community, especially in 33 Regencies / Cities in North Sumatera Province. The government should set the Regency / City Minimum Wage to be above the Workers' Decent Living Needs.

3. It is recommended that the government as policy makers and schools and universities as producers of the workforce can pay more attention to the quality of graduates in order to fill the available jobs. Graduates from the education level of the workforce should have the potential or skills needed by the company so that there is no missmatch or a mismatch between the skills possessed by workers and the company's workforce needs.

\section{REFERENCES}

Algifari, (2000), Analisis Regresi : Teori, Kasus, dan Solusi. Edisi 2, BPFE, Yogyakarta.

Arianti, Fitrie., Permana, Anggit Yoga (2012). Analisis Pengaruh PDRB, Pengangguran, Pendidikan, Dan Kesehatan Terhadap Kemiskinan Di Jawa Tengah Tahun 20042009. Diponegoro Journal Of Economics (2012) Vol. I Nomor I, Tahun 2012

Anderson, Courtney Lauren. (2012). Opening Doors: Preventing Youth Homelessness Through Housing and Education Collaboration. Seattle Journal for Social Justice, 11(2).

Bureau of Labor Statistics. (2013). A Profile of The Working Poor 2011. Federal Publication.Washington, DC: Cornell University ILR School.

Boediono, (1999). Teori Pertumbuhan Ekonomi, BPFE UGM, Yogyakarta.

Badan Pusat Statistik, (2009), Beberapa Data Pokok Kondisi Kesejahteraan Rakyat Dan Ekonomi Provinsi Sumatera Utara Tahun 2009, Sumatera Utara.

Badan Pusat Statistik, (2010), Beberapa Data Pokok Kondisi Kesejahteraan Rakyat Dan Ekonomi Provinsi Sumatera Utara Tahun 2010, Sumatera Utara.

Badan Pusat Statistik, (2011), Beberapa Data Pokok Kondisi Kesejahteraan Rakyat Dan Ekonomi Provinsi Sumatera Utara Tahun 2011, Sumatera Utara.

QE Journal | Vol.08 - No.02 - 76 
Badan Pusat Statistik, (2012), Beberapa Data Pokok Kondisi Kesejahteraan Rakyat Dan Ekonomi Provinsi Sumatera Utara Tahun 2012, Sumatera Utara.

Badan Pusat Statistik, (2013), Beberapa Data Pokok Kondisi Kesejahteraan Rakyat Dan Ekonomi Provinsi Sumatera Utara Tahun 2013, Sumatera Utara.

Badan Pusat Statistik, (2014), Beberapa Data Pokok Kondisi Kesejahteraan Rakyat Dan Ekonomi Provinsi Sumatera Utara Tahun 2014, Sumatera Utara.

Dinas Transmigrasi dan tenaga Kerja Provinsi Sumatera Utara (2016). Upah Minimum Kabupaten/Kota 2009-2013, Sumatera Utara.

Bank Dunia, (2006), Era Baru Dalam Pengentasan Kemiskinan Di Indonesia. The World Bank Office Jakarta.

Carey, K. (2002). State Povertyu-Based Education Funding: A Survey Of Current Programs And Options For Improvement

Chambers, Robert. (1983). Rur 76 elopment: putting the last first. Harlow: Prentice Hall.

Dewi, M.H.U., Endrayani Ni Ketut Eni, (2016). Analisis Faktor-Faktor Yang Mempengaruhi Tingkat Kemiskinan Kabupaten/Kota di Provinsi Bali. E-Journal Ekonomi dan Bisnis Universitas Udayana 5.1 (2016) :63-68

Imam Ghozali, (2005). Aplikasi Analisis Multivariate Dengan Program SPSS.BP Undip: Semarang.

Juwita, Ratna. (2013). Analisis Pengaruh Undereduction Terhadap Pendapatan Tenaga Kerja Sektoral Di Kota Palembang. Jurnal IImiah STIE MDP Vol. 2 No.2 : 150-158

Gaiha, R. (1993). Design of Poverty Alleviation Strategy in Rural Areas. Roma: FAO.

Gilarso, Drs. T. S. (2003). Pengantar Ilmu Ekonomi Makro, Edisi Revisi, Penerbit Kanisius (Anggota IKPI), Yogyakarta.

Green, William H, (2000). Econometric Analysys. New Jersey : Prentice-Hall.

Gujarati, Damodar, (2003), Basic Econometrics, Fourth Edition. McGraw-Hill

Companies, New York.

Hariani, Prawidya. (2011), Analisis Penyerapan Tamatan Perguruan Tinggi di Propinsi Sumatera Utara Tahun 2011. Jurnal Manajemen dan Bisnis, Vol 11. No. 02 Oktober 2011, 140-

Hermanto S., Dwi W., (2006), Dampak Pertumbuhan Ekonomi Terhadap Penurunan Penduduk Miskin di Indonesia : Proses Pemerataan dan Pemiskinan, Direktur Kajian Ekonomi, Institusi Pertanian Bogor.

Jhingan, M. (2003). Ekonomika Pembangunan Dan Perencanaan. Jakarta: P.T. Raja Grafindo Persada. 
Jonaidi, Arius. (2012). Analisis Pertumbuhan Ekonomi dan Kemiskinan di Indonesia. Jurnal Kajian Ekonomi, Vol 1. No. 1 April 2012, 140-164.

Kacem, Rami Ben Haj. (2012). Monetary versus Non-Monetary Pro-Poor Growth: Evidence from Rural Ethiopia between 2004 and 2009. Economics Discussion Papers. No $2012-62$.

Khabhibi, Achmad, (2013). Analisis Faktor-Faktor yang Mempengaruhi Tingkat

Kemiskinan, USM, Surakarta.

Mahmudi. (2007). Manajemen Kinerja Sektor Publik. UPP STIM YKPN. Yogyakarta..

Maipita, Indra., Jantan, M.D., Razak, Noor Azam Abd. (2010). Dampak Kebijakan Fiskal Terhadap Kinerja Ekonomi dan Angka Kemiskinan di Indonesia. Buletin Ekonomi Moneter dan Perbankan Bank Indonesia 12,4 (421-456)

Maipita, Indra. (2013). Memahami dan Mengukur Kemiskinan. Absolue Media. Yogyakarta

Maipita, Indra. (2014). Mengukur Kemiskinan dan Distribusi Pendapatan. UPP STIM YKPN. Yogyakarta:

Maipita, Indra. (2013). Simulasi Dampak Kenaikan Upah Minimum Terhadap Tingkat Pendapatan dan Kemiskinan. Jurnal Ekonomi dan Keuangan, Vol.17 No. 3 September 2013, (391-410).

Mankiw, N.G., D.Romer, dan D. Weil. (1992). A Contribution to The Empirics of the Economic Growth. Quarterly Journal of Economics, 127(2): h: 407-437

Mankiw Gregory, 2006 Pengantar Ekonomi Makro, Edisi Ketiga, Salemba Empat, Jakarta.

Mudrajad, Kuncoro (2006). Ekonomika Pembangunan: Teori, Masalah, dan Kebijakan, UPP Akademi Manajemen Perusahaan YKPN.

Nurske, Ragnar. (1952). Problems of Capital Formation in Underdeveloped Countries, Oxford : Basil Backwell.

Parwadi, Redatin. (2013). Model Pengentasan Kemiskinan Di Era Otonomi Daerah. Untan Press. Pontianak

Putri, I. A. S. M. dan N.N. Yuliarni (2013). Beberapa faktor yang mempengaruhi tingkat kemiskinan di Provinsi Bali. E-Journal Ekonomi pembangunan Univeristas Udayana 2(10): 441-448

Rachman, Hasanuddin, (2005), Pengaruh Pengupahan Sebagai langkah Strategis Stabilitas Dalam Hubungan Industrial. Jakarta.

Rachmawati, I.K. (2008), Manajemen Sumber Daya Manusia. Penerbit Andi. Yogyakarta.

Rasidin K. Sitepu dan Bonar M. Sinaga, (2004). Dampak Investasi Sumber Daya ManusiaTerhadap Pertumbuhan Ekonomi Dan Kemiskinan Dilndonesia: Pendekatan Model Computable General 
Riva, Vinny Alvionita., dkk (2014). Pengaruh Tingkat Pengangguran Dan Tingkat Upah Minimum Provinsi Terhadap Tingkat Kemiskinan Di Provinsi Riau. JOM FEKON Vol 1 No. 2 Oktober 2014.

Sasana, Hadi. (2009). Peran Desentralisasi Fiskal Terhadap Kinerja Ekonomi di Kabupaten/Kota Provinsi Jawa Tengah. Jurnal Ekonomi Pembangunan, Vol. 10. No. 1 Juni 2009, 103-124

Simanjuntak, Payaman J, (2001). Pengantar Ekonomi Sumber Daya Manusia, Jakarta: Fakultas Ekonomi UI.

Suharto, Edi. (2009). Kemiskinan dan Perlindungan Sosial di Indonesia, Menggagas Model Jaminan Sosial Universal Bidang Kesehatan. CV. Alfabeta. Bandung.

Sumarsono, Sony. (2003). Ekonomi Manajemen Sumber Daya Manusia dan Ketenagakerjaan. Graha Ilmu. Yogyakarta.

Suryahadi, A., Widyanti, W., Perwira, D., Sumarto, S. (2003), "Minimum Wage Policy and Its Impact on Employment in the Urban Formal Sector". Bulletin of Indonesian Economic Studies, 39(1), 29-50.

Suryawati, Chriswardani. (2005). Memahami Kemiskinan Secara Multidimensional. JMPK, Vol.8 No. 3 September 2005.

Suwarto. (2003). Hubungan Industrial dalam Praktik. Asosiasi Hubungan Industrial Indonesia, Jakarta.

Todaro, Michael P, (1994), Pembangunan Ekonomi di Dunia Ketiga, Edisi Kedua, , Jakarta: Erlangga.

Todaro, Michael P, (2000), Pembangunan Ekonomi di Dunia Ketiga, Edisi Ketujuh, Terjemahan Haris Munandar, Jakarta: Penerbit Erlangga.

Todaro, Michael, P., \& Stephen, S. (2004). Pembangunan Ekonomi, Edisi kesembilan. Jakarta: Erlangga.

Umar, Akmal. (2012) Pengaruh Upah, Motivasi Kerja, dan Kepuasan Kerja Terhadap Kinerja Pekerja Pada Industri Manufaktur di Kota Makassar. Jurnal Aplikasi Manajemen Vol.10 No. 2 Juni 2012.

Widodo, Adi, Waridin, \& K. Maria, Johana. (2011). Analisis Pengaruh Pengeluaran Pemerintah di Sektor Pendidikan dan Kesehatan Terhadap Pengentasan Kemiskinan Melalui Peningkatan Pembangunan Manusia di Provinsi Jawa Tengah. Jurnal Dinamika Ekonomi Pembangunan, Vol. 1. No. 1 Juli 2011, 25-42.

Wiguna, Van Indra. (2013). Analisis Pengaruh PDRB, Pendidikan Dan Pengangguran Terhadap Kemiskinan Di Provinsi Jawa Tengah Tahun 2005-2010. Jurnal Ilmu Ekonomi, Fakultas Ekonomi dan Bisnis Universitas Brawijaya Malang. 